Олег Цевельов,

кандидат наук з державного управління Національний університет оборони України імені Івана Черняховського, м. Київ

ORCID ID 0000-0003-4549-5505

Віктор Муженко, кандидат військових наук ORCID ID 0000-0002-5023-6463 Національний університет оборони України імені Івана Черняховського, м. Київ

DOI: $10.33099 / 2617-1775 / 2020-02 / 325-338$

\title{
ПІДГОТОВКА ФАХІВЦІВ ПРИКОРДОННОЇ СЛУЖБИ У ПЕРСПЕКТИВАХ РОЗВИТКУ СИСТЕМИ ВІЙСЬКОВОЇ ОСВІТИ
}

На сьогодні для України, в умовах ведення не об'явленої «гібридної війни», коли існує пряма загроза втрати суверенітету та територіальної иілісності держави, гостро постає питання щуодо підготовки воєнних кадрів силових відомств України саме тому, щзо необхідно для захисту національних інтересів країни. Це стосується на наш погляд не тільки Збройних Сил України, які в мирний час, так й під час війни постійно навчаються захищати державу, але й всіх інших військових формувань, утворених відповідно до законодавства Украӥни, у тому числі Державну прикордонну службу.

У статті провадиться аналіз наукових прачь щзодо вдосконалення підготовки майбутніх військових кадрів для прикордонних підрозділів та їх відповідність сучасним реаліям з якими зіткнулась краӥна.

Ключеві слова: прикордонна служба; безпека державного кордону; система військової освіти; досвід підготовки офіцерів; військова спеціалізаџія.

Постановка проблеми Досвід застосування військ (сил) у збройному конфлікті на сході держави переконливо свідчить, що забезпечення воєнної безпеки сьогодні потребує нових підходів до підготовки та застосування Збройних Сил та інших військових формувань, утворених відповідно до законодавства України.

Негативні зміни воєнно-політичної обстановки навколо України 3 2014 року, вирішення Державною прикордонною службою завдань із захисту незалежності та територіальної цілісності держави зумовили прийняття нових директивних та програмних документів, в яких визначені завдання щодо розвитку Державної прикордонної служби як військового формування, яке здатне забезпечити ефективну реалізацію політики безпеки у сфері захисту та охорони державного кордону України.

У Воєнній доктрині, яка затверджена Указом Президента України від 24 вересня 2015 року №555/2015 підкреслено, що основними цілями застосування Україною воєнної сили у разі збройного конфлікту на державному кордоні України $\epsilon$ забезпечення захисту державного кордону, ліквідація (локалізація, нейтралізація) збройного конфлікту на початковій стадії i недопущення його переростання у війну. Роль Державної прикордонної служби 
визначається у безпосередньої участі у припиненні збройного конфлікту на державному кордоні, боротьбі з тероризмом; припиненні збройних та інших провокацій на державному кордоні [1, с.8].

Це визначило конкретні зміни змісту та практичної направленості навчання прикордонників, врахування бойового досвіду й підготовки органів охорони державного кордону до охорони кордону в сучасних умовах. В той же час система підготовки прикордонників тактичного рівня в своїй основі (структура, освітньо-кваліфікаційні рівні, терміни навчання, основний зміст програм підготовки) залишається на рівні 2005 - 2014 років. Кардинальних змін за останні роки в системі підготовки прикордонників 3 воєнних дисциплін не відбулось.

На сьогодні під час організації навчального процесу майбутніх прикордонників слабо враховано досвід і тенденції щодо:

посилення ролі військового фактору у вирішенні міжнародних політичних, економічних, міжконфесійних, етнічних, історичних та інших конфліктів;

поширення діяльності екстремістських, терористичних організацій, збільшення можливостей незаконного переміщення засобів терору через державний кордон;

розроблення і випробування новітніх систем озброєння та військової техніки, включаючи роботизацію, принципів системного бойового застосування їх у зонах військових конфліктів;

зростання обсягів військово-наукових знань та використання штучного інтелекту у військовій сфері.

Враховуючи те, що на сьогодні Державна прикордонна служба України входить до складу сектору безпеки і оборони та виконує завдання із захисту територіальної цілісності держави, існує нагальна потреба до внесення змін в основні нормативно-правові документи у сфері безпеки державного кордону та покладання додаткових функцій на прикордонну службу 3 питань участі у бойових діях, що докорінно потребує перегляд системи підготовки майбутніх охоронців кордону.

Аналіз останніх досліджень і публікацій. Загальним напрямком наукових розвідок закордонних та вітчизняних авторів присвячені вивченню особливостей підготовки спеціалістів у навчальних закладах США, Німеччини, Польщі, Великобританії тощо. У наукових працях А. Балендра, С. Білявця, I. Блощинського, О. Диденка, В. Дияка, А. Некрасова, В. Оліферука, Л. Петрової, Ю. Приходька, Ю. Супрунова, В. Телелима, І. Толокі, Р. Шарана, Б. Шуневича та інших розглядаються особливості системи відбору та підготовки військових кадрів та прикордонників європейських держав, аналізується сучасний досвід та уніфікована програма підготовки персоналу збройних сил, у тому числі для прикордонної охорони в багатьох країнах Європейського Союзу. Водночас основна мета цих наукових досліджень полягає в удосконаленні процесів підготовки прикордонників для здійснення процедур прикордонного контролю та впровадження в повсякденну діяльність правоохоронних й правозастосовчих функцій.

Однак, проблема формування спеціаліста з безпеки державного кордону, 
компетентного вирішувати питання локалізації озброєних та інших провокацій, ведення бойових дій з незаконними військовими формуваннями та диверсійнорозвідувальними групами противника, патріотично стійкого та знаючого основи організації бою, що нажаль в умовах продовження воєнного конфлікту на території країни,залишається не вирішеною.

Формування цілей статті (постановка завдання). Метою статті $\epsilon$ аналіз основних проблем підготовки сучасних прикордонників України в умовах існуючих воєнних загроз національній безпеці у сфері захисту та охорони державного кордону й визначення заходів державного реагування для розвитку системи військової освіти.

Виклад основного матеріалу дослідження. Шостий рік наша держава живе i працює в умовах збройного конфлікту. I такі обставини суттєво актуалізують та загострюють потребу України в реформуванні Збройних Сил, Державної прикордонної служби та інших складових сектору безпеки і оборони задля збільшення можливостей у відстоюванні цілісності країни та державного суверенітету. Важливим кроком на цьому шляху став прийнятий Верховною Радою Закон України «Про внесення змін до деяких законів України щодо військових стандартів», яким внесено зміни до законів «Про оборону України» i «Про стандартизацію» відносно приведення національних військових стандартів до стандартів НАТО та Закон України «Про вищу освіту», яким запроваджено нові підходи до вищої військової освіти.

Відтак, проблема запровадження стандартів НАТО піднімає водночас і питання забезпечення сектору безпеки $\mathrm{i}$ оборони достатньою кількістю висококваліфікованих військових фахівців. На цьому ж наголошують і науковці А. Переверзєв, В. Оліферук, В. Телєлім. Відповідно до їхніх висновків, у розвинутих країнах на освіту військових звертають особливу увагу. Експерти та науковці підкреслюють, що в США, Великій Британії та Німеччині наприклад, офіцери на службі отримують таку якісну освіту, якої не знайти у найкращих навчальних закладах, оскільки, на думку аналітиків, там дуже серйозно ставляться до того, щоб люди, які ухвалюють рішення, були максимально освічені, мали достатній досвіт сучасних військових конфліктів та ведення бойових дій [2, с.24].

Водночас, як стверджують західні фахівці, за останній рік українські військові навчальні заклади Збройних Сил України суттєво вдосконалили систему освіти. Прогрес із впровадження підходів та принципів НАТО в галузі освіти - очевидний. На сьогодні відповідно до вимог Закону України «Про вищу освіту» запроваджується єдиний підхід до підготовки майбутніх військових кадрів. «Нині проваджуються нові вимоги Закону «Про вищу освіту», зокрема, щодо вищої військової освіти. Удосконалення законодавства вибудує єдине бачення та підходи щодо професійної військової освіти, тим самим наблизивши їх до підходів Альянсу у цій сфері», - наголошує Маріуш Соліс керівник Програми удосконалення військової освіти (Defence Education Enhancement Program - DEEP) [3].

Реформування військової освіти є одним з пріоритетних завдань розбудови сектору безпеки i оборони України. Фундаментом, який визначає розвиток 
військової освіти, є їі нова парадигма, яка нині широко обговорюється в колах фахівців у галузі військової освіти у зв'язку із зовнішніми та внутрішніми обставинами, що склалися.

Правовою основою реформ у галузі військової освіти є Конституція України [4], Закон України «Про вищу освіту» [5], Національна стратегія розвитку освіти в Україні на період до 2021 року [6], Національна доктрина розвитку освіти [7], Національна рамка кваліфікацій [8], Концепція військової освіти в Україні [9], законодавчі акти України з питань оборони й національної безпеки, зокрема Воєнна доктрина України [1], Стратегія національної безпеки України [10], Концепція розвитку сектору безпеки і оборони України [11], Стратегічний оборонний бюлетень України [12], інші нормативно-правові акти України.

У Концепції військової освіти в Україні визначено завдання реформування військової освіти в контексті загальної реформи Збройних Сил та інших військових формувань України. Зокрема в неї йдеться про уніфікацію військової освіти всіх вищих військових навчальних закладів, використання в практиці роботи передової методики підготовки збройних сил держав - членів НАТО, використання технологій дистанційного навчання, приведення змісту освіти та якості підготовки (перепідготовки) і підвищення кваліфікації військових фахівців у відповідність до потреб сил оборони та з урахуванням досвіду проведення антитерористичної операції та Операції об'єднаних сил [13, ст.15].

Відповідно до вимог ст. 12 Закону України «Про національну безпеку України» Державна прикордонна служба входить до складу сектору безпеки i оборони. Організаційно-правові механізми формування й реалізації державної політики забезпечення національної безпеки України у сфері захисту та недоторканості державного кордону і охорони суверенних прав в іï прилеглій території та виключній (морській) економічній зоні, які визначено законодавством країни, спрямовані на врегулювання проблемних питань договірно-правового оформлення спільних ділянок державного кордону із суміжними державами, дотримання режиму державного кордону та прикордонного режиму, функціонування пунктів пропуску та прикордонної інфраструктури, реадмісії осіб, прикордонно-представницької діяльності, а також питання нормативно-правового забезпечення діяльності суб'єктів забезпечення прикордонної безпеки [14].

На сьогодні, законодавство та нормативно-правове забезпечення захисту й охорони державного кордону, а також й підготовка прикордонників є значною мірою застарілими, а закладені норми щодо взаємодіій, координації дій органів державної влади (державного управління) i структур сектору безпеки та оборони (військового управління) як у мирний час, так і в особливий період не враховують особливостей нового типу зовнішньої агресії, під час якої широко застосовуються не лише традиційні військові операції, але й різноманітні невоєнні «гібридні» сили і засоби боротьби. Крім того, нормативно-правові акти в цій сфері містять низку неузгодженостей, підходи до визначення певних термінів мають бути переглянуті, потребують запровадження сучасних 
правових та практичних механізмів реагування на загрози національній безпеці у сфері безпеки державного кордону України, а також й підходи до підготовки майбутніх прикордонників.

Нинішня система підготовки висококваліфікованих кадрів тактичного рівня для прикордонної служби виявилася неготовою та слабкою до протидії сучасним викликам i загрозам у сфері забезпечення захисту державного кордону, зокрема ефективно протистояти зовнішній агресії шляхом ведення бойових дій із незаконними військовими формуваннями на державному кордоні та у прикордонних районах, на що як раз й вказують дії в Автономної Республіці Крим щодо протидії збройним силам суміжної держави та незаконним військовим формуванням на Сході України.

На сьогодні молоді офіцери-прикордонники слабо розбираються в формах и методах організації бойових дій, не мають уяви щодо планування бою та протидії диверсійно-розвідувальним групам противника, організації взаємодії та координації зусиль 3 підрозділами Збройних Сил та іншими військовими формуваннями України в ході припинення збройних та інших провокацій на державному кордоні. До цього часу в прикордонній службі відсутні нормативно-правові документи, а саме Статути прикордонної служби, настанови з оперативно-службової діяльності, роботи органів управління тощо. В результаті обмеженого фінансування прикордонного відомства практична підготовка прикордонників в ході проведення тактичних навчань зведена нанівець.

Враховуючи розширення воєнних функцій складових сектору безпеки i оборони, Державна прикордонна служба України, як й всі складові сектору оборони, потребує формування нової генерації військових керівників, особливо іiі офіцерського корпусу.

Аналіз нинішнього стану системи військової освіти, а також світових тенденцій та досвіду провідних країн-членів НАТО щодо розвитку освітньої галузі воєнних наук також засвідчує про наявність низки проблем і стримуючих чинників ефективного функціонування системи військової освіти в цілому, що зумовлені, здебільшого, новими викликами, які постали перед країною, іiі Збройними Силами та іншими військовими формуваннями і на які потрібно адекватно реагувати.

Починаючи з 2003 року із прийняттям Закону України «Про Державну прикордонну службу України», враховуючи досвід та рекомендації Європейських структур безпеки, відбувся процес переходу прикордонного відомства з суто військового до правоохоронного органу, реформування якого більше походила на поліцейські структури при цьому не враховувалися наявні загрози у сфері безпеки державного кордону.

На той час головними загрозами безпеки державного кордону вважалися організована міжнародна злочинність, міжнародний тероризм, контрабандна торгівля у тому числі наркотиками, зброєю та небезпечними матеріалами, торгівля людьми та людськими органами, нелегальна міграція. Тому в Свропі прикордонний контроль став розглядатися як передній край оборони Європейського Союзу проти нестабільності та їі наслідків. 3 метою посилення 
прикордонного контролю та об'єднання спільних зусиль прикордонних відомств Свропейського Союзу проти організованої міжнародної злочинності було застосовано концепцію інтегрованого управління кордонами, що підкреслює необхідність координації діяльності всіх суб'єктів, які мають відношення до безпеки кордонів. Організації та службовці, які виконують функції із забезпечення безпеки у прикордонних районах європейських країн, як правило, мають назву прикордонна поліція чи прикордонна охорона.

Водночас, оперативні потреби управління зовнішніми сухопутними кордонами Свропейського Союзу, в регіонах, де держави слабкі та відбуваються воєнні конфлікти, вторгнення озброєних банд, розглядаються питання щодо посилення прикордонних структур чи переведення їх до військових структур із посиленням їх бойових можливостей. Таким чином, діючи в небезпечній зоні, прикордонники мають традиційне походження 3 військовими підрозділами. Тому, навіть орієнтовані на поліцейський зразок прикордонна служба в умовах загрози воєнного характеру з боку інших держав повинна мати можливість міцного та швидкого реагування, спроможність якого залежить від дисципліни військового типу, на прикладі останніх подій на державному кордоні Туреччини та Греції [15, с.49-51].

Сучасний стан розвитку системи військової освіти це творчий пошук інноваційних технологій у педагогічних, практичних та психологічних галузях 3 метою вироблення політики оперативного та стратегічного управління прикордонними з'єднаннями та спроможністю адекватно реагувати на існуючи загрози національній безпеці на державному кордоні, враховуючи й придбаний досвід участі прикордонних підрозділів у складі сил антитерористичної операції та Операції об’єднаних сил.

Система військової освіти $є$ основним джерелом підготовки та комплектування Збройних Сил, Державної прикордонної служби та інших військових формувань України висококваліфікованими офіцерськими кадрами.

В контексті розвитку військової науки відбувається трансформація іiі складової - безпеки державного кордону. Під час існування Прикордонних військ України лева частина навчальних дисциплін у вищому навчальному прикордонному закладі приділялась саме військовим, вважалось, що прикордонні підрозділи не лише здійснюють охорону державного кордону, а також його захист шляхом введення бойових дій із незаконними військовими формуваннями та у разі агресії проти України здатні стримувати дії передових сил противника для забезпечення розгортання з'єднань та частин Збройних Сил України.

3 переходом прикордонного відомства від суто військового формування до правоохоронного органу спеціального призначення було внесено зміни в навчальний процес та збільшено кількість навчальних дисциплін правоохоронної діяльності замість військової компоненти.

На сьогодні в Національній академії Державної прикордонної служби України провадиться освітня діяльність за наступними навчальними дисциплінами військово-прикордонної компоненти за бакалаврським i магістерським рівням вищої освіти з виділенням відповідних кредитів СКТС на 
їх вивчення. Перший (бакалаврський) рівень вищої освіти - безпека державного кордону, основний - підготовка офіцерів прикордонної служби для основних підрозділів - відділів прикордонної служби:

тактика прикордонної служби - 27 кредитів (810 годин);

прикордонний контроль - 18 кредитів (540 годин);

загальна тактика - 25 кредитів (750 годин, включаючи бойове забезпечення, воєнно-інженерну підготовку, топографію, захист від зброї масового ураження та тактичну підготовку);

вогнева підготовка - 14 кредитів (420 годин);

фізичне виховання - 10 кредитів (300 годин).

Другий (магістерський) рівень вищої освіти - безпека державного кордону, підготовка офіцерів для штабів органів охорони державного кордону та керівників оперативного рівня:

оперативно-службова діяльність Державної прикордонної служби України - 22 кредити (660 годин);

діяльність штабів Державної прикордонної служби та Збройних Сил України - 17 кредитів (510 годин);

тактика та оперативне мистецтво Збройних Сил України - 10 кредитів (300 годин);

бойове забезпечення і тактика родів військ - 10 кредитів (300 годин).

Враховуючи те, що воєнні дисципліни для прикордонного відомства не $\epsilon$ на сьогодні основними, за сукупністю кількості годин офіцери прикордонники як першого, так й другого освітнього рівня отримують базову воєнну підготовку та здатні виконувати завдання лише на рівні - командира мотопіхотного взводу, що є не достатньої для керівників органів охорони кордону.

Відповідно до вимог закону України «Про національну безпеку України» Державна прикордонна служба входить до складу сектору безпеки і оборони, таки чином сили і засоби прикордонного відомства входять як до сектору оборони, тобто безпосередньо для участі із захисту територіальної цілісності держави та відсічі збройної агресії, так й до сектору безпеки - забезпеченні недоторканості державного кордону та охорони суверенних прав України в іiі виключній (морській) економічній зоні [14].

Таким чином прикордонна служба призначена по-перше - для захисту державного кордону - направлення зусиль для недопущення виникнення озброєних та інших провокацій на державному кордоні, спроможності ліквідування озброєного чи неозброєного конфлікту на державному кордоні чи у контрольованому прикордонному районі власними силами чи у взаємодії із приданими підрозділами правоохоронних органів і Збройних Сил України 3 метою недопущення переростання такого конфлікту в збройне протистояння чи повномасштабну агресію; по-друге - для здійснення контролю за порядком перетинання державного кордону, режимом державного кордону, прикордонним режимом у контрольованих прикордонних районах та охороною суверенних прав України в її виключній (морській) економічній зоні. 
Практика застосування прикордонних підрозділів в Операції об'єднаних сил на території окремих районів Донецької та Луганської областей вказує на те, що прикордонники виконують не лише суто правоохоронні функції (ведення оперативно-розшукової діяльності, пропуск осіб через лінію зіткнення у визначених дорожніх коридорах, протидія контрабандній діяльності), а також суто військові дії - прикриття контрольних пунктів в’їзду-виїзду, участь у пошуку та знищенні диверсійно-розвідувальних груп противника та знаходячись у загальновійськовому резерві для виконання інших бойових завдань.

Виконання цих функцій потребує від прикордонника, як висококваліфікованого військового спеціаліста не тільки знання прикордонного контролю, а й знань та умінь організації бойових дій, ведення військової розвідки, маскуванні своїх дій та проводити у складі Сил спеціальних операцій пошук й ліквідацію диверсійно-розвідувальних груп противника.

Враховуючи специфіку застосування прикордонних підрозділів на сучасному етапі реформування Державної прикордонної служби України доцільно було б взяти за основу особливості підготовки та порядок застосування фахівців для Прикордонної охорони Фінляндії. Досвід підготовки прикордонників Фінляндії є для нас цікавим з огляду на наявність сухопутних та морських кордонів й те, що Прикордонна охорона цієї країни відповідає за захист і охорону зовнішніх кордонах Європейського Союзу. Вона $\epsilon$ військовою організацією, що підпорядкована міністрові внутрішніх справ Фінляндії і Президенту країни. Водночас у разі загрози виникнення військового конфлікту на державному кордоні чи повномасштабної війни, Прикордонна охорона входить до складу збройних сил та підпорядковується міністрові оборони Фінляндії. Підготовка офіцерського складу організовано у навчальних закладах збройних сил (Академії національної оборони).

Навчальна програма підготовки майбутніх прикордонників передбачає вивчення питань управління військами, загальновійськової тактики, тактики видів оборонних сил, військової педагогіки, техніки, природничо-математичних дисциплін, політики безпеки і стратегії, історії, іноземних мов та фізичної підготовки [16, ст.259].

Підготовка кваліфікованих воєнних кадрів Збройних Сил та інших військових формувань, утворених відповідно до законодавства України повинно здійснюватися за єдиними планами та програмами включаючи й специфіку військових формувань. На це направлено вимоги Концепції військової освіти України, що була затверджена ще в 1997 році та зі змінами 2005 року, головною метою якої є збереження досягнення вищої військової школи України, iï науково-педагогічний потенціал, забезпечити якість підготовки військових фахівців відповідно до сучасних вимог, зменшити витрати на їх підготовку, сформувати і забезпечити розвиток високих моральних якостей громадянина України та захисника Вітчизни. Сдина система військової освіти як складова частина державної системи освіти України призначена для підготовки фахівців усіх освітньо-кваліфікаційних рівнів для 
підрозділів, частин, з'єднань Збройних Сил, МВС, Національної гвардії, СБУ, Держприкордонслужби, МНС та НКАУ [6].

Аналіз стандартів вищої освіти за спеціальностями галузі знань «Військові науки, національна безпека, безпека державного кордону» вказує на відсутність єдиних підходів до цілій, методів та кінцевих результатів підготовки військовослужбовців Збройних Сил та інших військових формувань, утворених відповідно до законодавства України. Розроблені стандарти за відповідними спеціальностями у кожному із силових відомств різняться по суті та структурно не пов'язані між собою. Особливо це стосується підготовки офіцерських кадрів оперативного рівня.

На тактичному рівні підготовки офіцерських кадрів такий підхід обумовлений специфікою підготовки спеціалістів кожного силового відомства, водночас основи та стандарти 3 військової підготовки для всіх збройних формувань, особливо, що входять до сил оборони, повинні бути єдиними. На сьогодні спорідненість в програмах підготовки офіцерів тактичного рівня спостерігається лише між військовими інститутами Збройних Сил та Національної гвардії України. Військовослужбовці Державної прикордонної служби України за військовими дисциплінами мають лише базову підготовку для офіцерів запасу (39 кредитів, 1170 годин).

Магістерський (оперативний) рівень підготовки військових фахівців має за мету підготовку висококваліфікованих воєнних кадрів для органів управління силових відомств та повинен бути єдиним. Офіцери оперативного рівня всіх військових формувань, особливо сектору оборони, повинні мати знання 3 питань оперативного планування, порядку взаємодії та виконання завдань під час спільних операцій кожним із силових відомств, чітко розуміти роль і місця органів військового управління кожного військового формування. Водночас, на сьогодні підготовка офіцерських кадрів оперативного рівня силових відомств України здійснюється за різними програмами та в окремих випадках, як уДержавній прикордонній службі України фактично за тією ж самою, що й тактичного рівня.

Уніфікація вищої військової освіти, особливо на оперативному рівні, повинна створити умови для поєднання стандартів підготовки офіцерських кадрів Збройних Сил та інших військових формувань, утворених відповідно до законодавства України. Така підготовка повинна проводитися на базі одного спеціалізованого університету за відповідною єдиною програмою для всіх офіцерських кадрів сектору оборони, що розглядаються або прагнуть бути керівниками оперативного рівня. Це надасть позитивні результати у порядку спільних підходів до розуміння організації оборони держави.

В умовах сьогодення доцільність проведення уніфікації військової освіти всіх військових вищих навчальних закладів стоїть дуже гостро. Враховуючи вимоги єдиної нормативно-правової бази військової освіти та 3 метою іiі уніфікації нами пропонується здійснювати підготовку військовослужбовців за відповідною послідовністю, а саме:

на першому рівні знань (тактичному) здійснювати підготовку молодших фахівців за напрямками діяльності, при цьому військові науки повинні займати 
половину програми навчання. Підготовка спеціалістів проводиться у відомчих вищих навчальних закладах, навчальних центрах або на військових кафедрах цивільних вищих навчальних закладах;

на другому рівні знань (тактичному та оперативному) - підготовка фахівців здійснюється за напрямками спеціалізації у відомчих вищих навчальних закладах, при цьому військові науки також повинні займати половину програми навчання та бути спорідненими 3 програмою навчання вищих навчальних закладів Збройних Сил України;

на третьому рівні знань (стратегічному) - підготовка фахівців повинна здійснюватися виключно в Національному університеті оборони за єдиною програмою для всіх силових відомств. Таким чином офіцери в ланці від бригади до керівників оперативно-тактичних угруповань, регіональних чи територіальних управлінь будуть розуміти єдині підходи до оборони держави, порядок взаємодії видів, родів військ на інших військових формувань під час планування спільних операцій.

Висновок. Вивчення, аналіз, узагальнення зарубіжного досвіду підготовки кадрів сектору безпеки та оборони США, Канади, Німеччини, Ізраїлю, Польщі, Фінляндії [17] враховуючи та не відкидаючи власний досвід підготовки свідчать про необхідність впровадження комплексу заходів, спрямованих на удосконалення системи підготовки кадрів для сил безпеки і оборони України.

По-перше, потребує створення нової уніфікованої організаційно-штатної структури сектору безпеки та оборони України, перегляд чисельності офіцерського корпусу всіх військових формувань, визначення доцільного співвідношення між категоріями офіцерського складу, потреби у підготовці кадрів для різних рівнів управління, що в подальшому потребує і перегляду структури системи військової освіти, системи підготовки та підвищення кваліфікації офіцерського складу Збройних Сил, Державної прикордонної служби та інших військових формувань України.

По-друге, одним із чинників, що сприяє функціонуванню системи стратегічного управління кадровими процесами в секторі безпеки і оборони це створення єдиної уніфікованої програми військової освіти підготовки військових кадрів для Збройних Сил, Держприкордонслужби та інших військових формувань. Необхідно чітко визначитися із завданнями та функціями, які виконують кожна складова сектору безпеки i оборони у загрозливий період та у разі введення правового режиму воєнного стану. Це наддасть певне уявлення в якому об'ємі готувати воєнні кадри кожного військового формування України.

По-третє, виходячи $з$ досвіду підготовки кадрів сектору безпеки і оборони у зарубіжних країнах на першому плані стоїть практичне спрямування навчання, що зорієнтовано на вирішення конкретних практичних завдань. Вважається, що головною складовою як процесу навчання, так і перепідготовки та підвищення кваліфікації воєнних кадрів сектору безпеки і оборони України також повинна стати практична складова, яка полягає у наближенні навчання до реальних умов службової діяльності шляхом збільшення обсягу практичних 
занять на бойовій техніці, залучення слухачів до участі у військових навчаннях та тренуваннях.

По-четверте, слід відзначити, що система підготовки воєнних кадрів більшості розвинених країн Свропи має такі особливості, як чітко виражена спеціалізація, інтенсивність та короткостроковість навчального процесу. Доцільно було б глибоко вивчити дане питання та розглянути систему підготовки військових щодо скорочення строків навчання, а більше уваги приділити практичному досвіду. Впровадження в освітній процес новітніх форм навчання таких як дистанційне навчання без відриву від виконання своїх службових обов'язків.

По-п’яте, у зарубіжних країнах значні зусилля спрямовані саме на якісний відбір кадрів для сил безпеки і оборони. В результаті ретельного відбору кандидатів суттєво знижується вірогідність потрапляння до лав спецпідрозділів випадкових осіб. Вважаємо, що на Україні така система відбору кандидатів є не досконалою, особливо, що стосується систем медичних та психологічних заходів профвідбору, особливо це стосується питання роботи 3 військовослужбовцями строкової служби. 32008 року Державна прикордонна служба відмовилась від цієї категорії військовослужбовців, але починаючи 3 2015 року через великий некомплект у підрозділах кордону, вимушена знов призивати на службу військовослужбовців строкової служби. Водночас за період відсутності у підрозділах такої категорії військовослужбовців втрачено методику та порядок роботи з призовниками.

Сьогоднішні потенційні виклики та загрози національній безпеці України у сфері захисту та охорони державного кордону зумовлюють нагальну потребу удосконалення законодавчого, нормативно-правового та наукового забезпечення прикордонної безпеки України, що спрямовані на створення системи надійного захисту державного кордону спільно з всіма складовими сектору безпеки та оборони, підвищення рівня боєздатності органів i підрозділів Державної прикордонної служби та їх спроможності до виконання завдань із захисту державного кордону та реінтеграції тимчасово окупованих i неконтрольованих територій.

\section{ЛІТЕРАТУРА}

1. Указ Президента України №555/2015 «Про рішення Ради національної безпеки і оборони України від 2 вересня 2015 року «Про нову редакцію Воєнної доктрини України»» від 24 вересня 2015 p. [Електронний ресурс]. - Режим доступу: http://zakon5.rada.gov.ua/laws/show/555/2015.

2. Телелим В., Тимошенко Р., Приходько Ю. Військова освіта в системі безпеки та оборони // Наука і оборона. 2013. № 4. С.21-28.

3. Міністерство оборони України. Офіційний сайт. XVII Міжнародний тиждень НАTO 28 квітня 2017 [Електронний ресурс]. - Режим доступу : http://mil.gov.ua

4. Конституція України [Електронний ресурс]. - Режим доступу: http://zakon3.rada.gov.ua/laws/show/2254к/96-вр.

5. Закон України №1556-VII «Про вищу освіту» від 1 липня 2014 р. [Електронний ресурс]. Режим доступу : http://zakon4.rada.gov.ua/laws/show/1556-18/page2.

6. Указ Президента України №344/2013 «Про Національну стратегію розвитку освіти в Україні на період до 2021 року» від 25 червня 2013 року [Електронний ресурс]. - Режим 
доступу : http://zakon3.rada.gov.ua/laws/show/344/2013.

7. Указ Президента України №347/2002 «Про Національну доктрину розвитку освіти» від 17 квітня 2002 року [Електронний ресурс]. - Режим доступу: https://zakon.rada.gov.ua/laws/show/347/2002.

8. Постанова Кабінету Міністрів України №1341 «Про затвердження Національної рамки кваліфікацій» від 23 листопада 2011 р. [Електронний ресурс]. - Режим доступу: http://zakon3.rada.gov.ua/laws/show/1341-2011-п.

9. Постанова Кабінету Міністрів України №1410 «Про створення єдиної системи військової освіти» від 15 грудня 1997 року зі змінами № 1170 від 26 вересня 2007 року [Електронний ресурс]. - Режим доступу : https://zakon.rada.gov.ua/laws/show/1410-97$\% \mathrm{D} 0 \% \mathrm{BF}$.

10. Указ Президента України №5287/2015 «Про Стратегію національної безпеки України» від 24 вересня 2015 року [Електронний ресурс]. - Режим доступу: http://zakon5.rada.gov.ua/laws/show/287/2015.

11. Указ Президента України №92/2016 «Про рішення Ради національної безпеки i оборони України від 4 березня 2016 року «Про Концепцію розвитку сектору безпеки i оборони України»» від 14 березня 2016 р. [Електронний ресурс]. - Режим доступу: http://zakon2.rada.gov.ua/laws/show/92/2016.

12. Указ Президента України «Про рішення Ради національної безпеки і оборони України від 20 травня 2016 року «Про Стратегічний оборонний бюлетень України»» [Електронний ресурс]. - Режим доступу : https://zakon.rada.gov.ua/laws/show/n0006525-16.

13. Телелим В.М., Приходько Ю.І. Стан і тенденції розвитку військової освіти у провіднихкраїнах світу в контексті їх обороноздатності // Збірник наукових праць Військового інституту КНУ ім.Т.Г. Шевченка. - 2012. - Вип. № 36 - С.6-17.

14. Закону України № 2469-VIII «Про національну безпеку України» від 21 червня 2018 р. [Електронний ресурс]. - Режим доступу : https://zakon.rada.gov.ua/laws/show/2469-19

15. Віллем Ф. ван Іінкелен, Филипп Х. Флурі. Побудова оборони та безпеки // Збірник матеріалів Плану партнерських дій щодо створення інститутів оборони та безпеки (РАРDIB). - Київ - Женева, 2007. С.415.

16. Білявець С. Тенденції професійної підготовки фахівців прикордонних відомств у провідних країнах Європи в XX - XXI століттях. // Молодий вчений. №7 (47) липень 2017 р. C.257-262.

17. Толок І., Супрун Ю. Особливості підготовки військових фахівців тактичного рівня у ВВНЗ США та окремих країн НАТО // Наука і оборона. 2016. №3. С.259-271.

\section{REFERENCES}

1. Ukaz Prezidenta Ukrainu №555/2015 “Pro rishenny Radu nastionalnoy bezpeku i oboronu Ukrainu vid 2 veresny 2015 roky "Pro novy redakstiy Voennoi doktrinu Ukrainu" vid 242 veresny 2015 roky. [Electronyi resyrs]. - Rejum dostypy : http://zakon5.rada.gov.ua/laws/show/555/2015.

2. Telelim V., Timoshenko R., Prixodko Y. Viyskova osvita v sistemi bezpeku i oboronu // Nayka i oborona. 2013. № 4. C.21-28.

3. Ministerstvo oboronu Ukrainu. Ofistiunui sait. XVII Mijnarodnui tujden NATO 28 kvitna 2017 [Electronyi resyrs]. - Rejum dostypy : http://mil.gov.ua.

4. Konstitustia Ukrainu [Electronyi resyrs]. - Rejum dostypy : http://zakon3.rada.gov.ua/laws/show/2254к/96-вр.

5. Zakon Ukrainu №1556-VII "Pro vushy osvity" vid 1 lupna 2014 r. [Electronyi resyrs]. Rejum dostypy : http://zakon4.rada.gov.ua/laws/show/1556-18/page2.

6. Ukaz Prezidenta Ukrainu №344/2013 “Pro Nastionalnu strategiy rozvitky osvitu v Ukraini na period do 2021 roky" vid 25 chervna 2013 roky [Electronyi resyrs]. - Rejum dostypy: http://zakon3.rada.gov.ua/laws/show/344/2013.

7. Ukaz Prezidenta Ukrainu №347/2002 “Pro Nastionalnu doktriny rozvitky osvitu” vid 17 


\begin{tabular}{llllllll}
\hline kvitna & 2002 & roky & [Electronyi & resyrs]. & - & Rejum & dostypy :
\end{tabular}

https://zakon.rada.gov.ua/laws/show/347/2002.

8. Postanova Kabinety Ministriv Ukrainu №1341 "Pro zatverdjenna Nastionalnoi ramku kvalifikastii” vid 23 listopada 2011 r. [Electronyi resyrs]. - Rejum dostypy : http://zakon3.rada.gov.ua/laws/show/1341-2011-п.

9. Postanova Kabinety Ministriv Ukrainu №1410 "Pro stvorenna edinoi sistemu viiskovoi osvitu" vid 15 grydna 1997 roky zi zminami № 1170 vid 26 veresna 2007 roky [Electronyi resyrs]. - Rejum dostypy : https://zakon.rada.gov.ua/laws/show/1410-97-\%D0\%BF.

10. Ukaz Prezidenta Ukrainu №5287/2015 "Pro Strategiy nastionalnoi bezpeki Ukrainu” vid 24 veresna 2015 roky [Electronyi resyrs]. - Rejum dostypy : http://zakon5.rada.gov.ua/laws/show/287/2015.

11. Ukaz Prezidenta Ukrainu №92/2016 "Pro rishena Radu nastionalnoy bezpeku i oboronu Ukrainu vid 4 berezna 2016 roky "Pro Konstepstiy rozvitky sektory bezpeku i oboronu Ukrainu"” vid 14 berezna 2016 r. [Electronyi resyrs]. - Rejum dostypy : http://zakon2.rada.gov.ua/laws/show/92/2016.

12. Ukaz Prezidenta Ukrainu №92/2016 "Pro rishena Radu nastionalnoy bezpeku i oboronu Ukrainu vid 20 travna 2016 roky "Pro Strategichnii oboronii buleten Ukrainu"” [Electronyi resyrs]. - Rejum dostypy : https://zakon.rada.gov.ua/laws/show/n0006525-16.

13. Telelim V.M., Prixodko Y.I. Stan I tendenzii rozvitky viiskovoi osvitu y providnux krainax svity v koneksti ix oboronozdatnosti // Zbirnuk naykovux prast Viiskovogo instutyty KNY im. T.G.Shevchenka. - 2012. - Vup. №36 - C.6-17.

14. Zakon Ukrainu №2469-VIII "Pro nastionalny bezpeky Ukrainu” vid 21 chervna 2018 r. [Electronyi resyrs]. - Rejum dostypy : https://zakon.rada.gov.ua/laws/show/2469-19.

15. Villem F. van Iinkelen, Filipp X. Flyri. Pobydova oboronu ta bezpeki // Zbirnuk materialiv Plany partnerskix dii chodo stvorena instutytiv oboronu ta bezpeki (PAP-DIB). - Kyiv Geneva, 2007. C.415.

16. Bilavest $\mathrm{S}$. Tendenstii profesinoi pidgotovki faxivstiv prikordonux vidomstv y providnux krainax Evropu v XX - XXI stolitta. // Molodui vchtnui. №7 (47) lupen 2017 r. C.257-262.

17. Tolok I., Sypryn Y. Osobluvosti pidgotovki viiskovux faxivstiv taktuchogo rivna y VVNZ USA ta okremux krain NATO // Nayka I oborona. 2016. №3. C.259-271.

\section{PEЗЮМЕ}

Олег Цевелев, кандидат наук с государственного управления Национальный университет обороны Украины имени Ивана Черняховского

Виктор Муженко, кандидат военных наук Национальный университет обороны Украины имени Ивана Черняховского

\section{Подготовка специалистов пограничной службы в перспективе развития системы военного образования}

Сегодня для Украины, в условиях ведения необъявленной «гибридной войны», когда существует прямая угроза утрать суверенитету и территориальной иелостности государства, остро стоит вопрос о подготовке военных кадров силовых ведомств Украинь именно тому, что необходимо для защчтты национальных интересов страны. Это относится на наш взгляд не только для Вооруженных Сил Украины, которые как в мирное время, так и во время войнь постоянно учатся защчщуать государство, но и для всех остальных военных формирований, созданных в соответствии с законодательством Украины, в том числе и Государственную пограничную службу. 
В статье проводиться анализ научных работ по совершенствованию подготовки будущих военных кадров для пограничных подразделений и их соответствие современным реальностям, с которыми столкнулась страна.

Ключевые слова: пограничная служба; безопасность государственной границы; система военного образования; опыт подготовки офицеров; военная специализащия.

\section{SUMMARY}

Oleg Tsevelyov, candidate of sciences in public administration National Defence University of Ukraine named after Ivan Cherniakhovskyi

Victor Muzhenko, candidate of military sciences National Defence University of Ukraine named after Ivan Cherniakhovskyi

\section{Training of border service specialists in the prospects of development of the military education system}

Introduction. Today, for Ukraine, in the context of an undeclared "hybrid war", when there is a direct threat of loss of sovereignty and territorial integrity of the state, the question of training military personnel of Ukrainian law enforcement agencies is acute precisely because it is necessary to protect national interests. In our opinion, this applies not only to the Armed Forces of Ukraine, which in peacetime and during the war are constantly learning to defend the state, but also to all other military formations formed in accordance with Ukrainian legislation, including the State Border Service.

Purpose. The purpose of the article is to analyze the main problems of training modern border guards of Ukraine in the context of existing military threats to national security in the field of protection and protection of the state border and identify measures of state response to the development of military education.

Methods. The article analyzes scientific works on improving the training of future military personnel for border units and their compliance with modern realities faced by the country.

Results. The peculiarities of the system of selection and training of military personnel and border guards of European states are considered, the modern experience and the unified program of training of personnel of the armed forces, including for border guards in many countries of the European Union are analyzed.

Originality. Given that today the State Border Guard Service of Ukraine is part of the security and defense sector and performs tasks to protect the territorial integrity of the state, there is an urgent need to amend the main legal documents in the field of state border security and assign additional functions to the border service on participation in hostilities, which fundamentally requires a review of the training system for future border guards.

Conclusion. The problem of forming a specialist in state border security, competent to address the localization of armed and other provocations, fighting with illegal military formations and sabotage and reconnaissance groups of the enemy, patriotic and knowledgeable basis of the organization of combat, which unfortunately in a continuing military conflict in the country, remains unresolved.

Key words: border service; state border security; military education system; experience of officer training; military specialization. 